\title{
ICT COMPETENCIES OF FIRST-YEAR UNIVERSITY STUDENTS
}

\author{
Daiva Rimkuvienè \\ Faculty of Informatics, Vytautas Magnus University (Lithuania)
}

\begin{abstract}
University students need to be able to work with the information resources that they find for the purposes of their learning activity critically and have the competencies in resolving scientific issues in projects and studies independently. Also, they need to be able to use information effectively regarding its various forms. In recent years, the level of digital literacy among students has not been questioned. The students of higher education often consider themselves as competent users of information resources since they grew up in a world saturated with information and communication technologies (ICT). However, without a thorough study, it is difficult to identify the ways and means of improving the level of digital literacy of university students. The aim of the article is to assess digital literacy skills among the students at the Agriculture Academy of Vytautas Magnus University in Lithuania. The article presents the empirical results of the survey performed in autumn 2019 among first-year students. Data were collected through the completion of self-evaluation questionnaires and the assessment of the exam results. A possible limitation was the validity of student reflections regarding their abilities related to ICT competencies. The results show that although many first-year students had prior experience in technologies, a need to educate students on the basic ICT literacy skills needed at the university level remains. The study results are useful as curricular guidelines.
\end{abstract}

Keywords: ICT competence, digital literacy, first-year students, university.

\section{Introduction}

The basic ICT knowledge and skills that an ICT literate person should have are constantly being improved. Due to the rapid development of information and computer technologies, we are more and more frequently faced with the term ICT literacy and the broader meaning of the concept of information literacy, which constitute the fundament for modern society development. ICT literacy becomes an important precondition for socialisation and professional career. (Ivankovića A., Špiranec S., Miljko D., 2013). For university students, it is necessary to have knowledge and skills in the field of ICT to be able to use information effectively concerning its various forms. Among the reasonable factors of having ICT competency is the possibility for learners to access and obtain information from unlimited sources, communicate via computer and manage particular information for various purposes, for example, performing the tasks, for presentations, and data analysis.

The increasing demand for computer skills not only comes from many IT-producing jobs, such as computer hardware engineers and software programmers but also from the IT-using jobs, which encompass virtually every other job (Peng, 2017).

Information technology (IT) courses in Lithuania schools are mandatory for the $5-10^{\text {th }}$ grades for approximately 1 hour per week, respectively 35 hours per year. There are some optional modules as well (e.g., Programming). During the classes, integrative nature of the subject is being stressed: students are prompted to see parallels with other subjects, to employ modern methods, to differentiate contents, etc. Students of upper secondary schools $\left(11^{\text {th }}\right.$ and $12^{\text {th }}$ grades) can choose from advanced optional modules and have to learn the content defined in the course curriculum (Dagienè V., Stupuriene G., 2016). ICT skills are significantly crucial to many learners in higher education institutions. Students from rural areas do not always have favourable conditions for ICT learning, i.e. there is no opportunity to choose a school, it takes more time to reach the school or the lack of a motivating learning environment. Therefore, generally, more students who enter the Agriculture Academy have lower ICT skills compared to those who enter other institutions of higher education.

The aim of the article is to assess the ICT literacy skills among the students at the Agriculture Academy of Vytautas Magnus University in Lithuania. 
The t-test is applied to evaluate the statistically significant differences between the groups. Correlation analysis is performed to detect associations between variables. The data were processed with the statistical programme $R$.

\section{Results}

The study was carried out at the Agriculture Academy of Vytautas Magnus University. The data were collected in the Autumn semester of 2019 from evaluations of the introductory test, survey, interim assessments (quizzes) and results of examination (10-point grading system). The participants of the study were 109 first-year students from different faculties of the Agriculture Academy, 55.67\% were male and $44.33 \%$ were female. $52.58 \%$ of students completed Information Technologies classes in $10^{\text {th }}$ grade, and $39.18 \%$ of students - in $12^{\text {th }}$ grade.

At the beginning of the semester, students $(n=90)$ took the short online introductory test. The median of answers was 5.1 from 10 . Only $4.5 \%$ of students received a grade of at least 8 . This result can be explained by the fact that students started a new course after a summer holiday and they were unprepared. Besides, many students did not remember the fundamentals of the IT course due to the break after $10^{\text {th }}$ grade.

Further during the semester, the students $(\mathrm{n}=108)$ took two practical Excel quizzes. The first quiz included a number of questions related to the use of Excel formulas and its useful functions. The median of answers was 7 , mean -7.14 , and standard deviation -1.93 . The second quiz focused on creating and managing Excel tables and graphs. The median of answers was 8.5, mean -8.20 , and standard deviation -1.47 . A paired t-test $(\mathrm{t}=-5.9849$, $\mathrm{df}=106$, $\mathrm{p}$-value $=0.0000)$ shows the statistically significant differences between results of the first and the second practical tests.

During the semester, the students had to prepare a PowerPoint presentation and Word document (creating a table of contents, references, bibliography, style customising, etc.). The analysis of students' works showed that the students have good skills in PowerPoint programme and moderate skills in Word programme. This result can be explained by the fact that students prepare presentations not only during the IT classes but also during the classes of other subjects. Therefore, students usually get comments and suggestions for improvement from their teachers. Nevertheless, the teachers of other subjects do not check the formatting of the Word document, they are rather interested in the content.

At the end of the semester and before the exam, the students were asked to answer anonymously the online survey for self-evaluation purposes. The students self-assessed their competencies of Excel, Word, and PowerPoint programmes before and after the course (Fig. 1). The respondents have indicated that the lowest level of their skills refers to the Excel programme while the highest - to PowerPoint.

Figure 1. Results of students' self-evaluation.

PowerPoint

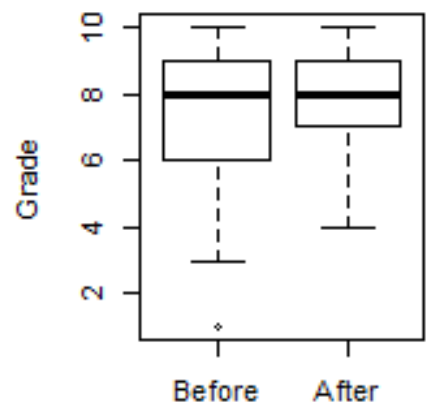

Word

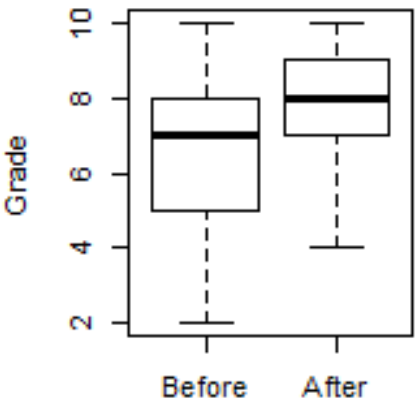

Excel

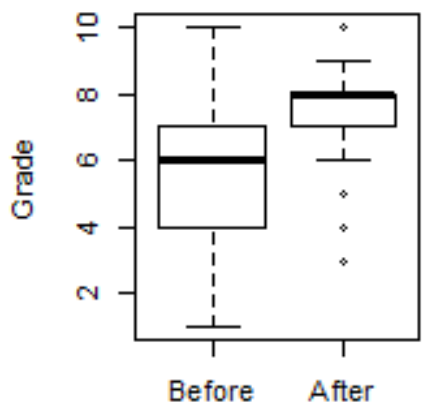

The respondents indicated that there was a significant improvement in their Excel and Word skills after the completion of the course.

Finally, the students took the exam. The exam consisted of the following parts: an online test and the practical quiz. The correlation between the results of the practical exam quiz, the first, and the second practical tests (Fig. 2) was low, i.e. 0.39 and 0.28 respectively $(\mathrm{p}<0.05)$. 
Figure 2. The relationship between the results of the practical exam quiz, the first, and the second practical quizzes.
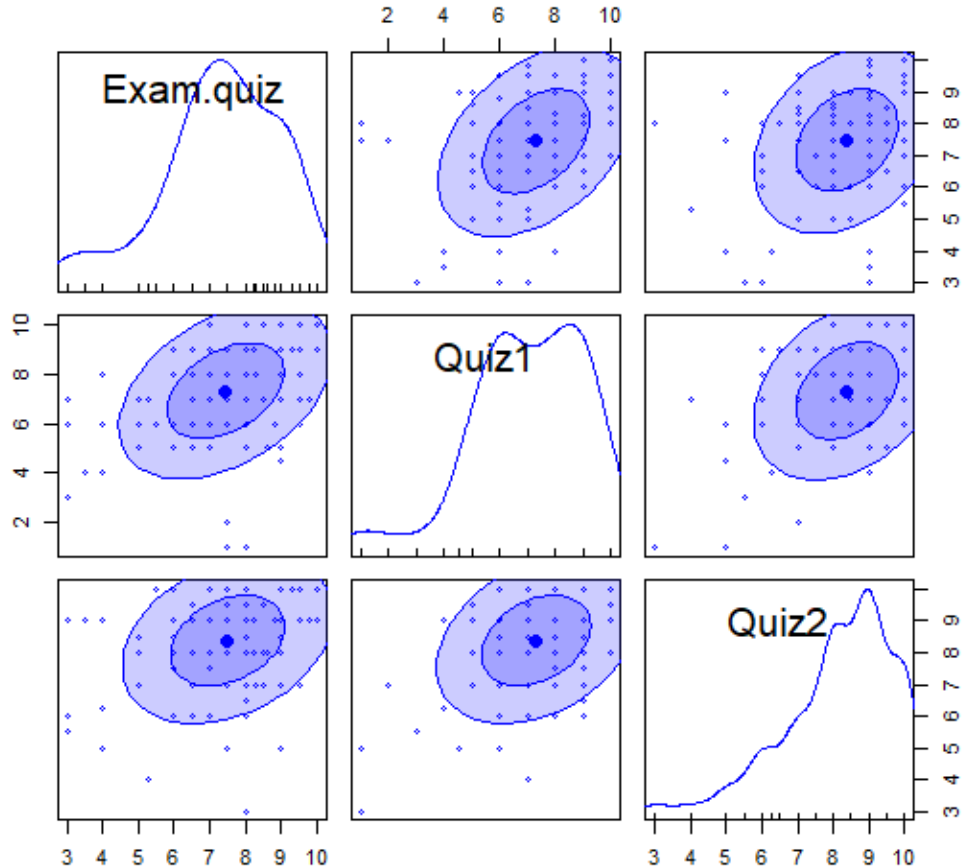

No significant differences between the exam results and students' self-evaluation were found. Also, no significant difference between the results of an online exam test and the results of the practical quizzes was detected. found.

No significant differences between the results and the self-evaluation according to sex were

\section{Conclusions}

The results regarding students' perceptions of their competencies in ICT indicate that they express an intermediate level of skills in ICT. No significant differences between the exam results and students' self-evaluation were detected.

First-year students of the Agriculture Academy were skilled at simple programmes like $M S$ Word, MS PowerPoint, and searching and browsing the Internet. However, they are less skilled at using MS Excel.

The study team considers that the data obtained from the study can be used as a basis for further studies on ICT literacy among students of Vytautas Magnus University and in the processes of identifying needs and interests of the university students to improve their ICT literacy.

\section{References}

Dagienè V., Stupuriene G. (2016). Informatics Concepts and Computational Thinking in K-12 Education: A Lithuanian Perspective. Journal of Information Processing Vol.24, No.4, 732-739.

Ivankovića A., Špiranec S., Miljko D. (2013). ICT literacy among the students of the Faculty of Philosophy, University of Mostar. Procedia - Social and Behavioral Sciences, $684-688$.

Peng, G. (2017). Do computer skills affect worker employment? An empirical study. Computers in Human Behavior, 74, 26-34. Retrieved from http://dx.doi.org/10.1016/j.chb.2017.04.013

Sunyoung Han, Yong Jeong Yi. (2019). How does the smartphone usage of college students affectacademic performance? Journal of Computer Assisted Learning, 35, 13-22. doi:https://doi.org/10.1111/jcal.12306 